University for Business and Technology in Kosovo

UBT Knowledge Center

Oct 27th, 4:45 PM - 6:15 PM

\title{
Foreign Direct Investments In Kosovo Opportunities, Challenges And Promotion
}

\author{
Hamëz Rama \\ University for Business and Technology, hamez.rama@ubt-uni.net
}

Follow this and additional works at: https://knowledgecenter.ubt-uni.net/conference

Part of the Business Commons

\section{Recommended Citation}

Rama, Hamëz, "Foreign Direct Investments In Kosovo Opportunities, Challenges And Promotion" (2017). UBT International Conference. 249.

https://knowledgecenter.ubt-uni.net/conference/2017/all-events/249

This Event is brought to you for free and open access by the Publication and Journals at UBT Knowledge Center. It has been accepted for inclusion in UBT International Conference by an authorized administrator of UBT Knowledge Center. For more information, please contact knowledge.center@ubt-uni.net. 


\title{
FOREIGN DIRECT INVESTMENTS IN KOSOVO OPPORTUNITIES, CHALLENGES AND PROMOTION
}

\author{
Hamëz Rama \\ ${ }^{1}$ UBT - Higher Education Institution, Lagjja KALABRIA p.n., Prishtinë, Kosovë \\ 10000 Prishtina, Kosovo \\ hamez.rama@ubt-uni.net
}

\begin{abstract}
Foreign direct investments in Kosovo are the basis for a genuine development, especially in the case of Kosovo that is in the transition phase from a former centralist system to the free market economy system. Investments are the most efficient way for a country's economic and political development, consolidation, economic growth, development and strengthening of the private sector.

The treatment and sensitization of foreign direct investment in Kosovo is a matter related to foreign direct investment (FDI), their importance, factors that influence the rise or fall of the level of foreign direct investment in Kosovo, potentials, opportunities and the challenges facing Kosovo in the transition period of state-building and government attempts for the country's economic development.

In the context of attempts by central institutions, the Kosovo Government is making continuous efforts to create development policies and other important actions to create a better environment for foreign direct investment, creating a climate that is most appropriate for investment, simultaneously for business development. To encourage developed countries that have interest and motive for FDI in Kosovo, the Republic of Kosovo has built a legal infrastructure and has approved the Law on Foreign Investments No. 04/220.

In addition to the legislative sphere, the institutions of the Republic of Kosovo also pay special attention to the promotion of these opportunities through the establishment of the Investment Promotion Agency (IPA-KIESA), in order to further promote Kosovo's potentials abroad, the climate of which Kosovo owns and the benefits it has if it invests in such a market as Kosovo.
\end{abstract}

Key words: foreign direct investment, Kosovo, opportunities, challenges, promotion, economic development

\section{Introduction}

Kosovo is the new state with its independence declared on 17February2008, which emerged after many years of occupation by Serbia, the last war of 1999 and the breakthrough from the former Yugoslavia. Kosovo after this period of war spent the recovery period and assistance from the international factor to a transition period of transformation political, economic, social and property system, etc.

Kosovo's economic development is impossible without the foreign direct investments with which investment is the most effective form of development and economic growth. Republic of Kosovo in continuity is making efforts to create macro-economic development policies, undertaking very important measures to create a favorable climate for development of the bidders, for the exercise 
of production and service activities of SMEs, the generation of countries new jobs and creating a suitable environment for foreign direct investment on Kosovo.

The Republic of Kosovo, in order to open foreign direct investment routes has built one legal infrastructure through the adoption of the Law on Foreign Investments No. 04/L-220, Article 2, point 1.4 ,say: "Foreign investment is any asset owned or legally held by a foreign person in the Republic of Kosovo for the purpose of performing legitimate commercial activities, these included but not limited to". 5

For foreign investors, as the main motive for investing in Kosovo are mining potentials, energy, agriculture, telecommunications, construction, wine tourism, tourism, and many other economic branches, but in particular the potential of the new population, about $65 \%$ dominates the age of under 35 . On the other side, you should look objectively and transparency that these investments are followed by the many challenges that they have identified in other countries that have passed the transition. As the challenges of foreign investors are followed by the rate of corruption, informality, etc, which stem as a result of the non-functioning of the rule of law.

Meanwhile, the promotion of investments, the Government of Kosovo did through MTI respectively KIESA, donor conferences, B2B, etc.

\section{Definition of Foreign Investments}

Based on scientific and economic literature we encounter different definitions of foreign investments. Investments are the process of engaging, mobilizing money or other production resources at the current moment in hope and in anticipation of some future assumed benefits. 6 Foreign direct investment is a form of investment that realizes profits in company, which operates outside the territory of the investor side, which require one business relationship between the company at the investor's place and its external affiliate. According to author Pierre Masse, the investments define as: "the essence of investments that make tolerance of sacrifice and denial of current consumption to increase the usefulness respectively increase consumption in the future".7

\section{Classification, Function and Efficiency of FDIs}

Foreign direct investment policy at different times in different countries is based on different attitudes.

We distinguish three types of approaches to foreign direct investment:

Restrictive attitude (closed market),

Liberal attitude (open market), and

Pragmatic national attitude. 8

Investments can be divided into two large groups:

- Real investment, and

- Financial investment.

Real investments are those that are made for the creation, expansion and modernization of physical assets, such as buildings, machinery, etc., while financial investments are those that are carried out for the purchase of financial instruments of the character of different valuable letters. 9

\footnotetext{
${ }^{5}$ Official Newspaper of the Republic of Kosovo No.01/09 january, 2014 Prishtina

${ }^{6}$ Edlira Luci \& Dorina Kripa, "Investments", Tirana 2007, p. 2

${ }^{7}$ Musa Limani "Applied Macroeconomics", Pristina 2008, p. 190

${ }^{8}$ Halil Kukaj, "International Business", Pristina 2014, p. 48

${ }^{9}$ Edlira Luçi \& Dorina Kripa, "Investments", Tirana 2007
} 
Economic development is closely related to the rate of reproduction of the main funds, especially those of production, respectively the activation of investments. Therefore, apart from economic factors, natural, human factors, investments represent the main material factor of the economic and social development of a country, so investments represent the function of increasing production, respectively production is the function of investments.

Investments have a particular impact on improving the economic structure and raising the living conditions of the population. The value of investment in this direction is that they have an impact on the growth of production capacities for the production of different material goods, which will serve to meet the needs of the population and to improve the standard of living. 10

So, the foreign investment function is heading towards growth, in global economic growth, they are of great importance to developing countries especially for Kosovo.

Investment efficiency in macroeconomic analysis is a very important indicator, which expresses the level of development, respectively the development of a country's productive forces. In the theory of economic development, it has been found that, besides the size and structure of investments, the efficiency of investments is a factor that is in line with the economic development of a country.

From an economic point of view, the efficiency of investments is seen by:

- the increase of production, respectively of the social product,

- national income,

- employment

- labor productivity, etc.

Government policies have an important role in the efficiency of foreign investment in their countries. Prosperous and developed countries governments make considerable efforts to encourage investment from abroad by their enterprises in order to provide opportunities to use natural resources or to increase the exports of machinery and equipment and at the same time generate capital inflows to improve the balance of payments. 11

The importance of investment relies on the formation of material-technical conditions, which enable the increase of technical labor availability, increase of labor productivity, etc.

\section{Foreign Direct Investment in Kosovo}

Foreign direct investments in Kosovo playing a decisive role in economic growth by restructure and increase the competitiveness of domestic industries, respectively economic branches, as well as investments can be transformed into employment opportunities i.e. the generation of new jobs, potential competitiveness of local businesses and penetration of these businesses into foreign markets.

The geographic position of our country enables communication, connectivity and a bridge between the countries of South Eastern Europe, i.e. Kosovo creates favorable conditions for foreign direct investment. Kosovo also provides the right environment for doing business, such as new and motivated labor force, free market and free access to customs in the European Union market, the lowest taxes in the region, as well as easy doing business procedures, are among the factors aimed at promoting as much foreign investment in our country.

On the other side, Kosovo's economy is characterized by low levels of industrial production, low level of investment, export deficit of products, high unemployment rate, and Kosovo has not yet stabilized economically and political, GDP growth is largely a result of donations and sending remittances from outside, not as a result of any economic activity.

${ }^{10}$ Muhamet Mustafa, "Investment Management", Prishtina 2005, p.28

${ }^{11}$ Muhamet Mustafa, "Investment Management", Prishtina 2005, ibidem 
Kosovo faces a number of social and economic problems, including:

$>$ The unstable political situation, which has made it difficult for Kosovo to absorb FDI;

$>$ External donations for capital investments have slowed down;

$>$ The ability of the banking system to derive long-term debt to support investments serious;

$>$ Lack of financial market and securities market;

$>$ Remittances from emigrants in their families which are decreasing as a consequence of emigration family members outside of Kosovo;

$>$ High level corruption;

$>$ High unemployment rate, etc. ${ }^{12}$

Direct Foreign Investments in Kosovo at the same time bring about increased resources such as:

- Additional capital,

- Technology,

- Management,

- Access to global markets,

- Access to regional markets,

- Increasing the percentage of exports, and

- Increase the level of production of products to meet their consumption needs. ${ }^{13}$

Foreign Direct Investment (FDI) received in Kosovo amounted to 215.9 million euro, which is lower compared to the 308.8 million euro recorded in 2015. The share capital and investment fund, which accounts for about 85.3 percent of total FDI, recorded the value of 179.0 million euro which is for 21.5 percent lower compared to the previous year. Also, FDIs in the form of debt instruments marked the value of 36.9 million Euros, a decrease compared to the previous year of 54.3 percent.

The decline in FDI was evident in almost all sectors. The most significant decline was in the real estate sector and the financial services sector, which was characterized by an annual decline of 11.6 and 70.5 percent. $^{14}$

Referring to these trends of Foreign Investments in Kosovo, we will present it the FDI comparison for the period 2007-2016.

Table 1. Foreign Direct Investment in Kosovo 2007-2016. 15

\begin{tabular}{|l|l|l|l|l|l|l|l|l|l|}
\hline $\mathbf{2 0 0 7}$ & $\mathbf{2 0 0 8}$ & $\mathbf{2 0 0 9}$ & $\mathbf{2 0 1 0}$ & $\mathbf{2 0 1 1}$ & $\mathbf{2 0 1 2}$ & $\mathbf{2 0 1 3}$ & $\mathbf{2 0 1 4}$ & $\mathbf{2 0 1 5}$ & $\mathbf{2 0 1 6}$ \\
\hline $\mathbf{4 4 0 . 7}$ & $\mathbf{3 6 9 . 9}$ & $\mathbf{2 8 7 . 4}$ & $\mathbf{3 6 8 . 5}$ & $\mathbf{3 8 4 . 4}$ & $\mathbf{2 2 9 . 1}$ & $\mathbf{2 8 0 . 2}$ & $\mathbf{1 5 1 . 2}$ & $\mathbf{3 0 8 . 8}$ & $\mathbf{2 1 5 . 9}$ \\
\hline
\end{tabular}

\footnotetext{
${ }^{12}$ Authorial overview

${ }^{13}$ http://www.slideshare.net/fitorezeqiri/tema-29856979

${ }^{14}$ CBK, "Annual Report 2016" Prishtina 2016, p. 31-32

${ }^{15}$ CBK, "Annual Report 2016" Prishtina 2016, p. 31-32(ibidem)
} 


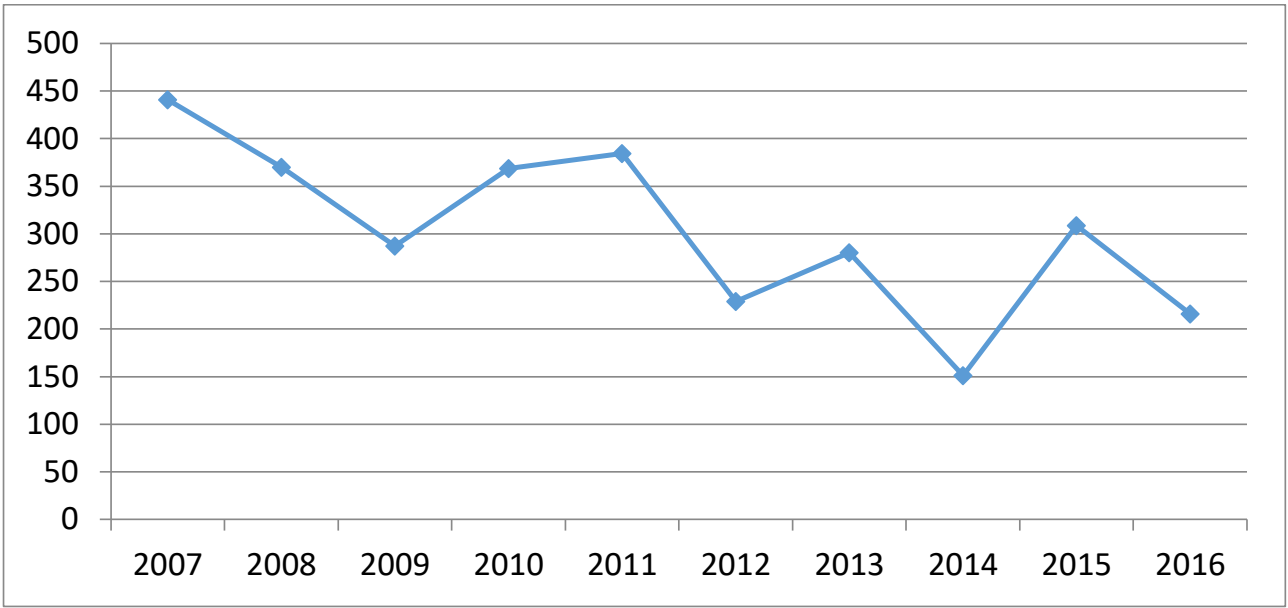

Fig.1. Foreign Direct Investment in Kosovo, as after years

Table 2. FDI in Kosovo as after the states, during the period 01.01-30.06.2017 16 mil.euro

\begin{tabular}{|l|l|l|l|l|l|l|l|l|l|l|l|}
\hline State & D & CH & AT & USA & UAE & GB & AL & TR & I & Other & Total \\
\hline Value & 29.7 & 22.8 & 20.4 & 11.9 & 11.2 & 10.8 & 8.8 & 8.3 & 2.5 & 12.8 & 139.2 \\
\hline & 29.7 & 22.8 & 20.4 & 11.9 & 11.2 & 10.8 & $\mathbf{8 . 8}$ & $\mathbf{8 . 3}$ & $\mathbf{2 . 5}$ & $\mathbf{1 2 . 8}$ & \\
\hline
\end{tabular}

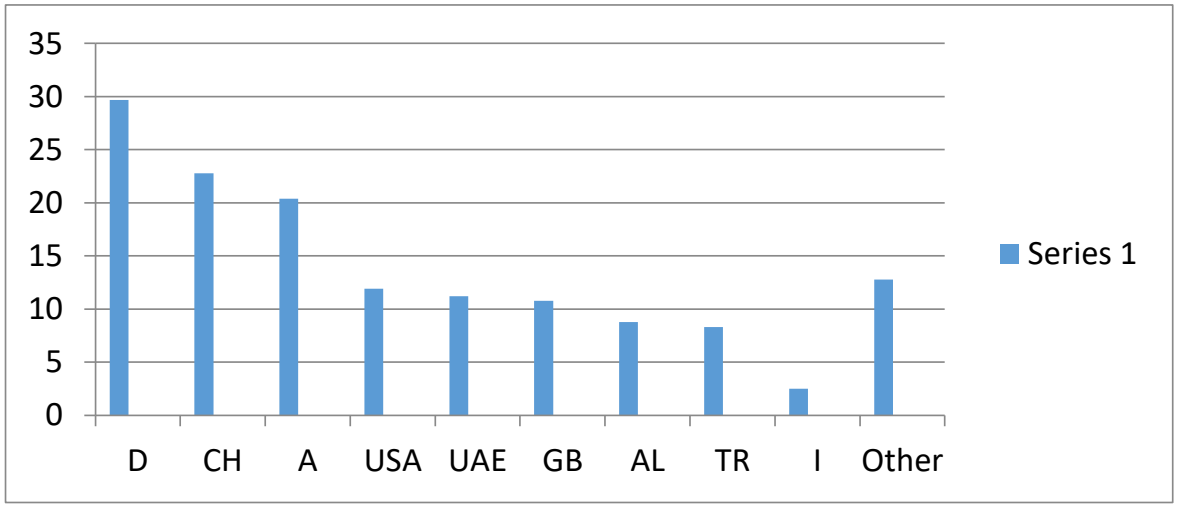

Fig 2. FDI in Kosovo as after the states, during the period 01.01-30.06.2017

${ }^{16}$ CBK, "Annual Report 2016" Prishtina 2016, p. 31-32(ibidem) 
Table 3. FDI by economic activity during January-June 2017. 17 mil.euro

\begin{tabular}{|c|c|c|c|c|c|c|c|c|c|c|c|c|}
\hline 党 & D & $\dot{\hat{Z}}$ & s & $\overline{0}$ & $\Sigma$ & U & Z & $\overleftarrow{0}$ & U్ & 兄 & 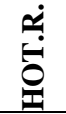 & $\mathbb{I}$ \\
\hline $\begin{array}{l}75 . \\
4\end{array}$ & $\begin{array}{l}37 . \\
6\end{array}$ & -4.1 & 6.7 & $\begin{array}{l}2 . \\
7\end{array}$ & 6.6 & -0.9 & 0.8 & 0.7 & 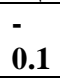 & 14.4 & 0.3 & $\begin{array}{l}\text { Valu } \\
\text { e }\end{array}$ \\
\hline
\end{tabular}

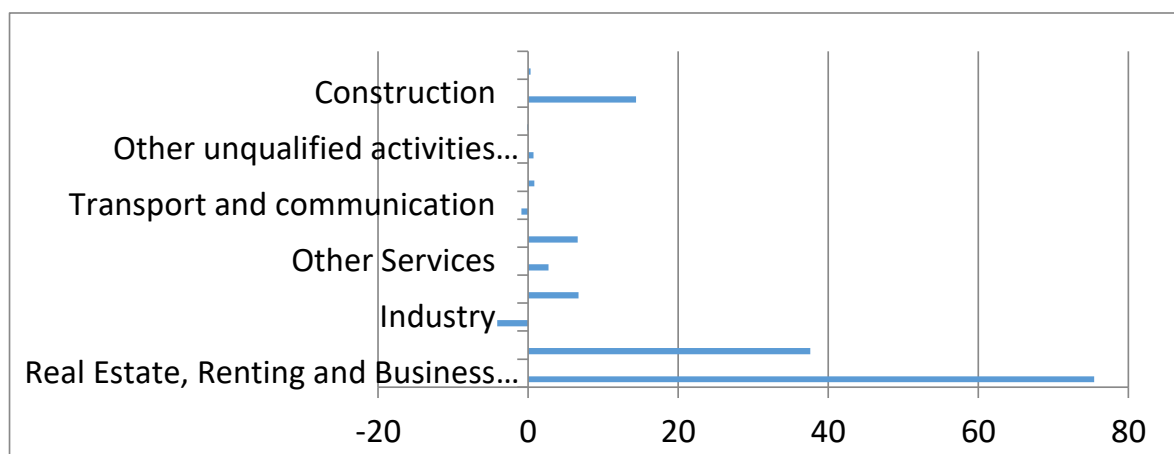

Fig. 3. FDI in Kosovo as a result of the economic activity during the period 01.01-30.06.2017

\section{Opportunities and Challenges of FDI in Kosovo}

Kosovo since the war has approached a free market system of the reformed economic system which equally provides opportunities to all foreign actors and investors.

These good opportunities are referred to in:

- legal infrastructure regulated and harmonized according to EU standards,

- Human resources with a new structure of 35 years old over $65 \%$ of the structure general population,

- good road infrastructure,

- access to all markets and investments in economic branches (energy, agriculture and tourism);

- Balanced macroeconomic policies,

- $\quad$ Fiscal policy reforms with the application of fiscal packages 1.0 and 2.0 with 22 measures ${ }^{18}$ which will be an incentive and additional incentive for FDI in Kosovo.

While on the other hand, Kosovo also faces challenges that constantly become a burden on consolidation and further economic development.

The most specific FDI challenges in Kosovo are:

- No political stability,

- The failure of the state and of the law,

- Poor combat of corruption and organized crime,

- Poor combating of economic informality.

${ }^{17}$ https://kiesa.rks-gov.net/page.aspx?id=1,17

${ }^{18}$ Source: Ministry of Finance of the Republic of Kosovo, Pristina 2017 


\section{Promotion of FDI in Kosovo}

Promotion is one of the most essential elements of a positive and attractive image building strategy for investors. Now Kosovo is a strategic place and is located in the center of the Balkans, which offers easy access through: transport road, rail and air transport, through the three ports located in:

-Selanik, Greece: 329.0 km, -Durrës, Albania: 262 km, Tivar (Bar), Montenegro: 299 km.

The pre-investment phase means the services offered to a foreign investor before the investment process in Kosovo by providing the following services:

- Help and advice on how to start a new business in Kosovo;

- Assistance in business registration procedures;

- Assistance in applying for licenses and permits required for business;

- Organization of meetings with local and central institutions and meetings with local and foreign businesses;

- Help to identify the ideal place to allocate business.

The investment phase means the investment process within which foreign companies are offered the following services:

- Help to find real estate to accommodate business;

- Assistance in applying and deploying through industrial zones and business incubators;

- Provide information on specific sectors, various projects and potential partners, with whom it can be collaborated;

The after-care investment, means the process within which the company that invested in Kosovo needs additional services, while the KIESA in this regard provides the aftercare project. In this process the current foreign company that has invested has the right to utilize the following services:

After-care service (afterwards care to investors).

- Assistance in organizing meetings and participating in conferences and B2B meetings;

- Notification of new changes in laws, taxes and other additional information. ${ }^{19}$

The investor initially refers to the link: https://kiesa.rks-gov.net/Page.aspx?id=1,1 can be informed about the structure, economic stability, macroeconomic policies, potentials and foreign investment opportunities in Kosovo.

${ }^{19}$ https://kiesa.rks-gov.net/page.aspx?id=1,42 


\section{Conclusions and recommendations}

\section{Conclusions}

Based on the free market economy system, technical-technological achievements, powerful global competitiveness, liberalization of markets and foreign direct investment play a key role in the process of Kosovo's economic integration. FDI in Kosovo is considered as a determining factor of economic growth, especially after independence and the transition process.

FDI is the main source of external financing in Kosovo. Foreign direct investment can increase the formation of fixed capital and assist in the balance of payments. FDI has the potential to generate employment, productivity growth, transfer capability and new technology, increase exports and contribute to the development long-term economic development of Kosovo. It means that we present impact of FDI-s economic development and growth in Kosovo, and the factors that have affected the changes that occurred in the periods presented. FDI impact on economic growth and functions of economic growth based the data used belong to the period from 20072016, the main factors influencing the adaptation of FDI in Kosovo, analysis of the perspectives mentioned.

This scientific work leave us understand the approach theoretical in terms of foreign direct investment, the primary goal to understand the motives of foreign investors, the advantages of foreign direct investment, FDI disadvantages, policies and objectives of FDI, which encourage foreign investors to invest in Kosovo, and to present the causes or factors that affect it in making investment decisions enterprises of particular importance for understanding the right way the role of FDI in Kosovo as the host country.

\section{Recommendations}

FDI started after the Declaration of Kosovo's Independence from 2008 onwards, which were focused on activities that have the cycle quick turnaround of capital that bring profit. Consider, by implementing the policy favorable for foreign investors will affect positively the seduction and motivation theirs. Based on the data and analysis of this paper, we consider it an urgent need of improvement and effort of conditions to lure investors based on the trends developmental growth, namely the reduction of FDI, most specifically in 2016. As a result of the ascertainment of the data, analyzes and conclusions mentioned above, The Government of the Republic of Kosovo, we recommend:

- Make the best economic and fiscal policies for favoring FDI,

- Develop free economic and customs zones,

- To create more space for business parks,

- Any foreign investor who creates a new job, to subsidize from 5,000-10,000 Eur.,

- Increase budget for promotional activities, and participation in fairs, and forums,

- To hold a donors' conference to unfolding agricultural resources, tourist and mining.

- Formalization of the informal economy, in works,

- Uncompromising war against corruption and negative phenomena in Kosovo. 


\section{References}

1. Central Bank of Kosovo, Annual Report 2016, Pristina 2016,

2. Edlira Luçi \& Dorina Kripa, "Investments" Tirana 2007,

3. Official Newspaper of the Republic of Kosovo No.01/09 january, 2014 Prishtina,

4. Halil Kukaj, "International Business", Prishtina 2014,

5. Muhamet Mustafa, "Investment Management", Prishtina 2005,

6. Ministry of Finance of the Republic of Kosovo, Pristina 2017,

7. Musa Limani, "Applied Macroeconomics", Prishtina 2008,

8. http: //www.slideshare.net/fitorezeqiri/tema-29856979,

9. https: //kiesa.rks-gov.net/page.aspx? Id $=1.17$,

10. https: //kiesa.rks-gov.net/page.aspx? Id $=1.42$ 